\title{
Inhibition of $\alpha$-amylase and $\alpha$-glucosidase activities in vitro by extracts of selected medicinal plants
}

\author{
DEEPAK RAJ PANT ${ }^{1, \bullet}$, BIVA ARYAL ${ }^{2}$, DAMA PUN ${ }^{1}$, SUSHILA SHARMA $^{1}$, GIRI PRASAD JOSHI ${ }^{1}$ \\ ${ }^{1}$ Central Department of Botany, Tribhuvan University. 44613 Kirtipur, Nepal. `email: deepak.pant@cdb.tu.edu.np \\ ${ }^{2}$ Department of Botany, Amrit Campus, Tribhuvan University. 44600 Kathmandu, Nepal
}

Manuscript received: 29 November 2020. Revision accepted: 9 February 2021.

\begin{abstract}
Pant DR, Aryal B, Pun D, Sharma S, Joshi GP. 2021. Inhibition of $\alpha$-amylase and $\alpha$-glucosidase activities in vitro by extracts of selected medicinal plants. Biodiversitas 22: 1187-1193. Several medicinal plants are being used traditionally in the treatment/management of Diabetes Mellitus (DM). The present work focuses on experimental verification of antidiabetic potential of different medicinal plants that have been reported to be used traditionally to manage DM. Aqueous and methanolic extracts of 12 species of plants were studied for their inhibitory effect on the activities of $\alpha$-amylase and $\alpha$-glucosidase, two key enzymes of carbohydrate metabolism. The extracts of all the species showed very high degree (nearly $90 \%$ or above) of inhibition of $\alpha$-amylase irrespective of the extraction solvent. However, the aqueous extracts of Asterella wallichiana, showed only $63.60 \%$ inhibition. Except for Asterella wallichiana, the percentage inhibition of $\alpha$-amylase in aqueous and methanolic solution in all the species tested were almost similar. The percentage inhibition of $\alpha$-glucosidase was lower than that of $\alpha$-amylase for all the species in both types of extraction medium. The highest percentage inhibition of $\alpha$-glucosidase $(81.13 \%)$ was found in methanolic extracts of Rhuschinensis. The inhibition of $\alpha$-glucosidase was much higher in methanolic extracts than in aqueous extracts for all the species tested. High degree of inhibition of $\alpha$-amylase activity in vitro by the extracts of all the species tested provides scientific basis for using these plants in the management/treatment of diabetes in traditional medicine.
\end{abstract}

Keywords: medicinal plants, methanolic extracts, diabetes, $\alpha$-amylase, $\alpha$-glucosidase

\section{INTRODUCTION}

Diabetes Mellitus (DM) is one of the most important public health problems faced by human society. An estimated 422 million adults were living with diabetes in the year 2014 (WHO 2016). DM is a physiological disorder in which blood sugar level increases and various metabolic activities like carbohydrate, fat, and protein metabolism are disturbed. Itis caused either by deficiency in insulin or inability of insulin to control blood glucose level. The former is called type 1 while the latter one is called type 2 diabetes (Farzaei et al. 2017). Among DM patients, about $10 \%$ suffer from type $1 \mathrm{DM}$ which normally develops as a result of a chronic progressive autoimmune disorder (Pietropaolo and Roith 2001). However, type 2 DM which accounts for more than $90 \%$ of diabetes worldwide, develops with increasing age (CDC 2007). Though, the exact cause of DM is not known for certain, the free radicals are believed to be involved in diabetes and related complications (Baynes and Thorpe 1996; Lipinski 2001).

Plants, the inexpensive natural source of antioxidants, are excellent antidiabetic medicines (Marles and Farnsworth 1995). There are 800 species of plants reported to have antidiabetic activity (Patil et al. 2011). Different groups of plants including bryophytes (Mukhia et al. 2017), pteridophytes (Ibraheim et al. 2011; Paul et al. 2012), and higher plants (Shim et al. 2003; Sah et al. 2015; Pranitha et al. 2014; Manandhar et al. 2011) have been reported to be used in the management/treatment of diabetes. Among the antidiabetic plants reported so far, the higher plants which account for nearly $95 \%$ of total extant flora are the most extensively studied group.

One of the approaches taken in managing DM, especially type 2 diabetes, is the use of various types of oral drugs with different modes of action to control hyperglycemia. The use of $\alpha$-glucosidase inhibitors like acarbose is one of such approaches (reviewed in Bosenberg and van Zyl 2008). Different medicinal plants used in the management of diabetes may also possess such inhibitors. Therefore, the study of the inhibitory potential of extracts of plants in question against different carbohydrate metabolism enzymes like $\alpha$-amylase and $\alpha$-glucosidase can be used as a tool to verify the antidiabetic effects of plant extracts in vitro.

In Nepalese context, studies on antidiabetic potential of medicinal plants are mostly related to documentation of ethnomedicinal aspects of plants in different parts of the country (Singh and Kumar 2017; Dahal 2016; Joshi 2011). There have been very few studies on experimental verification of the potential of those plants for diabetes control (Bhandari et al. 2008; Manandhar et al. 2012; Sah et al. 2015). Therefore, the present work focuses on experimental verification of antidiabetic potential of selected medicinal plants and their allied species belonging to different genera representing various groups like bryophytes (Asterella, Marchantia), pteridophytes (Adiantum, Oleandra, and Tectaria) and flowering plants (Hedychium, Rhus, Rubus, Smilax, and Sonchus) in terms 
of their ability to inhibit activities of $\alpha$-amylase and $\alpha$ glucosidase in vitro.

\section{MATERIALS AND METHODS}

\section{Plant materials}

Altogether, 12 plant species belonging to ten genera were selected for their antidiabetic potential in vitro. Plant samples of selected species and voucher specimens were collected from different parts of central Nepal (Table 1, Figure 1). Voucher specimens of respective plant materials were used for identification and authentication. The herbaria were deposited at the Tribhuvan University Central Herbarium (TUCH).

\section{Sample preparation}

The samples were cleaned and air-dried in shade until constant weight. The dried materials were ground to fine powder using grinder. The powdered mass was sieved through normal sieve and the fine powder was used for extraction procedure.

\section{Extract preparation}

Five gram of powder of each sample was taken and divided equally into two falcon tubes. Then respective solvent (water or methanol) was added to each tube up to $50 \mathrm{~mL}$ mark. The tubes were closed and vortexed briefly. The tubes were then subjected to sonication at $40 \mathrm{KHz}$ in the Sonicator (E-Chrom Tech, Taiwan UC-7240BDT) for 1 hour and filtered through Whatman No. 1 filter paper. The residue was subjected to solvent extraction as before and then filtered. Both filtrates were mixed and concentrated under reduced pressure in a rotary evaporator (RE 100 PRO, Dragon Lab China). The condensed extract thus obtained was transferred to clean and pre-weighed Petri plate. It was then allowed to evaporate at room temperature under a laminar airflow hood with regular blowing till constant weight. The dried extract was scraped off with a blade and collected in $2 \mathrm{~mL}$ polypropylene vials and stored at $4{ }^{\circ} \mathrm{C}$ until further use.

\section{Evaluation of antidiabetic activity}

Antidiabetic activity of the plant extracts in vitro was assessed by using inhibition assays for the enzymes of carbohydrate metabolism: $\alpha$-amylase and $\alpha$-glucosidase. $\alpha$ amylase inhibition assay was carried out following the protocol adopted by Ahmed et al. (2009) with slight modification. Reaction medium was prepared by dissolving Porcine pancreatic amylase (Sigma Aldrich, Germany) in $0.1 \mathrm{M}$ potassium phosphate buffer $(\mathrm{pH}$ 6.8) to a final concentration of $0.1 \mathrm{unit} / \mathrm{mL}$. Ten $\mu \mathrm{L}$ of either pure solvent (Control) or solutions of Acarbose or plant extracts in respective solvents (Samples) were mixed with $390 \mu \mathrm{L}$ of reaction medium in two test tubes. In one of the test tubes (Blank), $200 \mu \mathrm{L}$ of DNS reagent (Sigma Aldrich, Germany) was added to the above reaction mixture. The tubes were pre-incubated at $37^{\circ} \mathrm{C}$ for 10 minutes. Then 200 $\mu \mathrm{L}$ of $1 \%$ soluble starch (Fisher Scientific, India) was added and the tubes were incubated at $37^{\circ} \mathrm{C}$ for another 20 minutes. Then $200 \mu \mathrm{L}$ of DNS reagent was added in all the remaining tubes to stop the reaction. The tubes were then kept in boiling water bath for 10 minutes and then allowed to cool. The resultant mixture was then diluted by adding 4 $\mathrm{mL}$ of distilled water in each tube and absorbance was taken at $540 \mathrm{~nm}\left(\mathrm{~A}_{540}\right)$ in a UV/Vis spectrophotometer (EChrom Tech, Taiwan). Inhibition of $\alpha$-amylase activity was calculated by using the formula:

$\alpha$-Amylase Inhibition (\%) activity $=100 *\left(\mathrm{~A}_{540}\right.$ Control $\mathrm{A}_{540}$ Sample)/A ${ }_{540}$ Control

Similarly, $\alpha$-glucosidase inhibition assay was carried out following $\mathrm{Si}$ et al. (2010) with slight modification. Reaction mixture was prepared by dissolving p-nitrophenyl $\alpha$-D-glucopyranose (Sigma Aldrich, Germany) in $0.1 \mathrm{M}$ potassium phosphate buffer $(\mathrm{pH}$ 6.4) to a final concentration of $10 \mathrm{mM}$. The reaction mixture was dispensed to 96 well plates at the rate of $150 \mu \mathrm{L}$ per well. To the reaction mixture $10 \mu \mathrm{L}$ of pure solvent or solutions of Acarbose $(5 \mathrm{mg} / \mathrm{mL})$ or plant extracts $(1 \mathrm{mg} / \mathrm{mL})$ in respective solvents (water/methanol) were added. Respective blanks were prepared for each of the pure solvents and solution of plant extracts in respective solvents.

Table 1. Details of species, parts used and collection locality of plant samples

\begin{tabular}{|c|c|c|c|c|}
\hline Species & $\begin{array}{l}\text { Parts used } \\
\text { a) }\end{array}$ & $\begin{array}{l}\text { Collection } \\
\text { locality }^{\mathbf{b}} \text { ) }\end{array}$ & $\begin{array}{c}\text { Elevation } \\
\text { (m. asl) }\end{array}$ & Latitude and longitude \\
\hline Adiantum incisum Forssk. & WP & $\mathrm{I}$ & 1200 & $27^{0} 43^{\prime} 27^{\prime \prime} \mathrm{N} ; 85^{0} 06^{\prime} 32^{\prime \prime} \mathrm{E}$ \\
\hline Asterella wallichiana (Lehm.) Grolle & WP & II & 2100 & $28^{0} 13^{\prime} 03^{\prime \prime} \mathrm{N} ; 83^{0} 47^{\prime} 34^{\prime \prime} \mathrm{E}$ \\
\hline Hedychium coronarium J. Koenig & $\mathrm{RH}$ & III & 2050 & $27^{0} 34^{\prime} 54^{\prime \prime} \mathrm{N} ; 85^{0} 23^{\prime} 20^{\prime \prime} \mathrm{E}$ \\
\hline Marchantia polymorpha $\mathrm{L}$. & WP & III & 1515 & $27^{0} 35^{\prime} 35^{\prime \prime} \mathrm{N} ; 85^{0} 22^{\prime} 55^{\prime \prime} \mathrm{E}$ \\
\hline Oleandra wallichii (Hook.) C. Presl & RH & IV & 2500 & $27^{0} 35^{\prime} 40^{\prime \prime} \mathrm{N} ; 85^{0} 04^{\prime} 58^{\prime \prime} \mathrm{E}$ \\
\hline Rhus chinensis Mill. & BK & $\mathrm{V}$ & 1520 & $27^{0} 33^{\prime} 16^{\prime \prime} \mathrm{N} ; 85^{0} 37^{\prime} 34^{\prime \prime} \mathrm{E}$ \\
\hline Rhus succedanea $\mathrm{L}$. & BK & $\mathrm{V}$ & 1520 & $27^{0} 33^{\prime} 16^{\prime \prime} \mathrm{N} ; 85^{0} 37^{\prime} 34^{\prime \prime} \mathrm{E}$ \\
\hline Rubus niveus Thunb. & LS & VI & 1900 & $27^{0} 38^{\prime} 28^{\prime \prime} \mathrm{N} ; 85^{0} 15^{\prime} 46^{\prime \prime} \mathrm{E}$ \\
\hline Smilax aspera $\mathrm{L}$. & LV & III & 1690 & $27^{0} 37^{\prime} 16^{\prime \prime} \mathrm{N} ; 85^{0} 24^{\prime} 06^{\prime \prime} \mathrm{E}$ \\
\hline Smilax ferox Wall. ex Kunth & LV & III & 1680 & $27^{0} 37^{\prime} 16^{\prime \prime} \mathrm{N} ; 85^{0} 24^{\prime} 05^{\prime \prime} \mathrm{E}$ \\
\hline Sonchus arvensis L. & LV & VI & 1320 & $27^{0} 40^{\prime} 58^{\prime \prime} \mathrm{N} ; 85^{0} 17^{\prime} 12^{\prime \prime} \mathrm{E}$ \\
\hline Tectaria coadunata (Wall. ex Hook. and Grev.) C. Chr. & YF & VII & 800 & $28^{0} 08^{\prime} 41^{\prime \prime} \mathrm{N} ; 84^{0} 24^{\prime} 42^{\prime \prime} \mathrm{E}$ \\
\hline
\end{tabular}

Note: ${ }^{a}$ WP: whole plant; RH: rhizome; BK: bark; LS: leafy shoot; LV: leaves; YF: young fronds. ' $\mathrm{I}$ : Dhading, II: Parbat, III: Lalitpur, IV: Makawanpur, V: Kavrepalanchowk, VI: Kathmandu, VII: Lamjung 

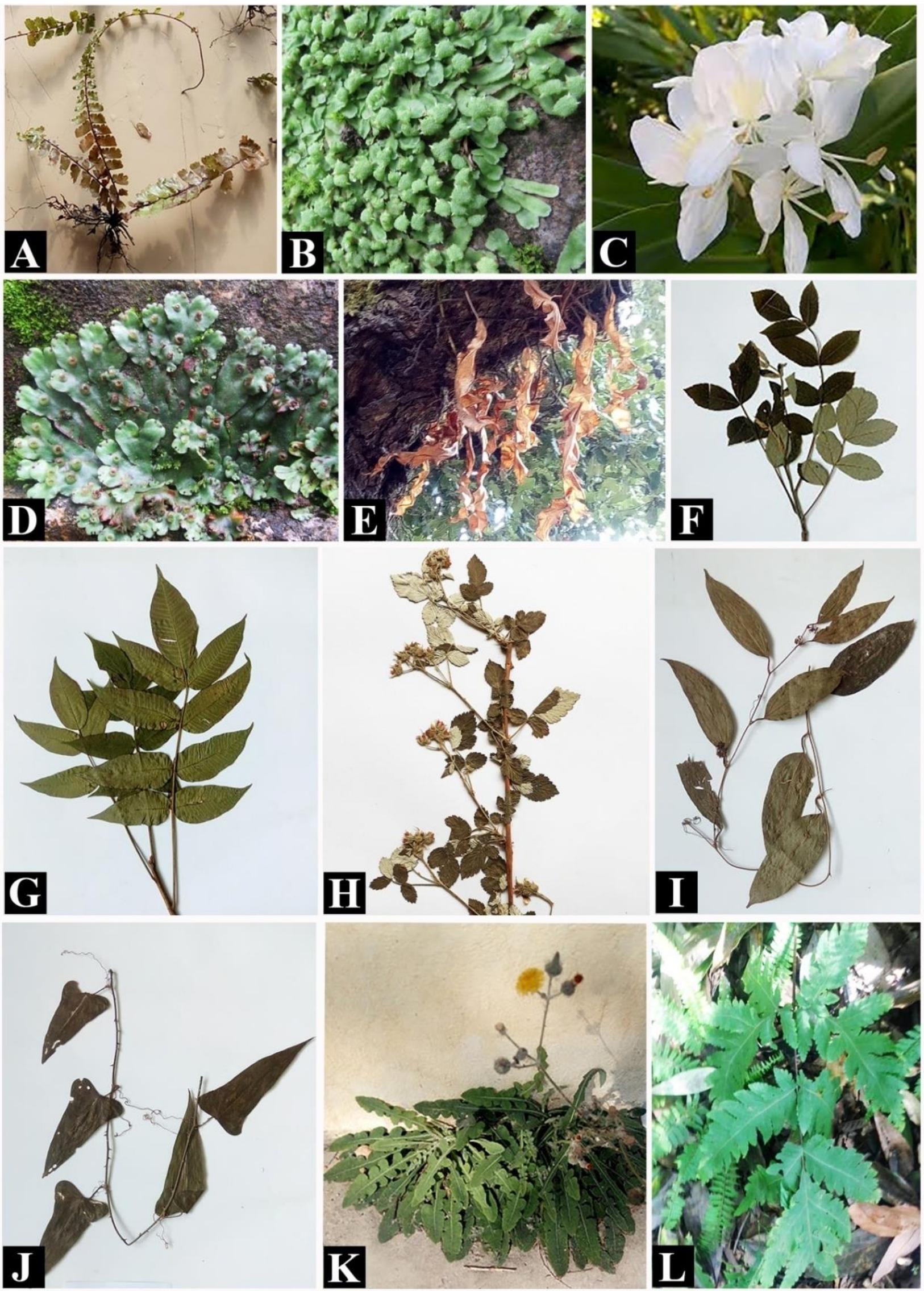

Figure 1. Photographs of selected medicinal plants: A. Adiantum incisum, B. Asterella wallichiana, C. Hedychium coronarium, D. Marchantia polymorpha, E. Oleandra wallichii, F. Rhus chinensis, G. R. succedanea, H. Rubus niveus, I. Smilax aspera, J. S. ferox, K. Sonchus arvensis, and L. Tectaria coadunata 
Then $40 \mu \mathrm{L}$ of $1 \mathrm{M} \mathrm{Na} \mathrm{CO}_{3}$ was added in all the wells representing the blank. The reaction mixture was preincubated at $30{ }^{\circ} \mathrm{C}$ for 10 minutes. After 10 minutes, $10 \mu \mathrm{L}$ of $\alpha$-glucosidase (Sigma Aldrich, Germany) solution (0.2 $\mathrm{U} / \mathrm{mL}$ ) prepared in phosphate buffer was added and the reaction mixture was incubated at $30{ }^{\circ} \mathrm{C}$ for $15 \mathrm{~min}$. Then $40 \mu \mathrm{L}$ of $1 \mathrm{M} \mathrm{Na}_{2} \mathrm{CO}_{3}$ was added in all the remaining wells. The absorbance was measured at $405 \mathrm{~nm}\left(\mathrm{~A}_{405}\right)$ in MultiscanEX (Thermo Fisher) Eliza plate reader. Inhibition of $\alpha$-glucosidase activity was calculated by using the formula:

$\alpha$-Glucosidase Inhibition $(\%)=100 *\left(\mathrm{~A}_{405}\right.$ Control $\mathrm{A}_{405}$ Sample)/A405 Control

\section{Data analysis}

All the experiments were performed in triplicates for each sample and values were reported as mean \pm S.D. All calculations were done using Microsoft Excel 2010.

\section{RESULTS AND DISCUSSION}

\section{Inhibition of $\alpha$-amylase activity in vitro by plant extracts}

Inhibition of $\alpha$-amylase activity by extracts of selected antidiabetic plants is shown in Figure 2. Except for aqueous extracts of Asterella wallichiana, all other extracts showed inhibition of $\alpha$-amylase activity comparable to that of acarbose, a standard antidiabetic drug. Among the aqueous extracts, the highest inhibitory activity $(99.15 \pm 1.48)$ and the lowest inhibitory activity $(63.6 \pm 6.4)$ was found in extracts of Smilax ferox and Asterella wallichiana, respectively. In methanolic extracts, the highest percentage inhibition of $\alpha$-amylase $(99.51 \pm 0.85)$ was found in Smilax aspera extracts while the lowest percentage inhibition $(90.00 \pm 6.93)$ was found in Oleandra wallichii extracts.

\section{Inhibition of $\alpha$-glucosidase activity in vitro}

Inhibition of $\alpha$-glucosidase activity by extracts of selected medicinal plants is shown in Figure3. In all species, the methanolic extracts showed high degree of inhibition of $\alpha$-glucosidase activity over aqueous extracts. Among the aqueous extracts, the highest inhibitory activity $(21.64 \pm 0.7)$ and the lowest inhibitory activity $(5.89 \pm 0.41)$ was found in extracts of Hedychium coronarium and Adiantum incisum, respectively. The inhibition of $\alpha$ glucosidase activity in aqueous extracts was comparable to acarbose in Asterella wallichiana, Rhus succedanea, Smilax ferox, and Tectaria coadunata, and higher than that of Acarbose in Marchantia polymorpha, Oleandra wallichii, Rhus chinensis, Rubus niveus and Smilax aspera. In the case of methanolic extracts, the highest percentage inhibition of $\alpha$-glucosidase $(81.13 \pm 1.36)$ was found in Rhus chinensis extracts while the lowest percentage inhibition $(21.22 \pm 1.07)$ was found in Smilax aspera extracts. With the exception of Smilax aspera the extracts of all other species showed higher inhibition of $\alpha$ glucosidase activity than acarbose.

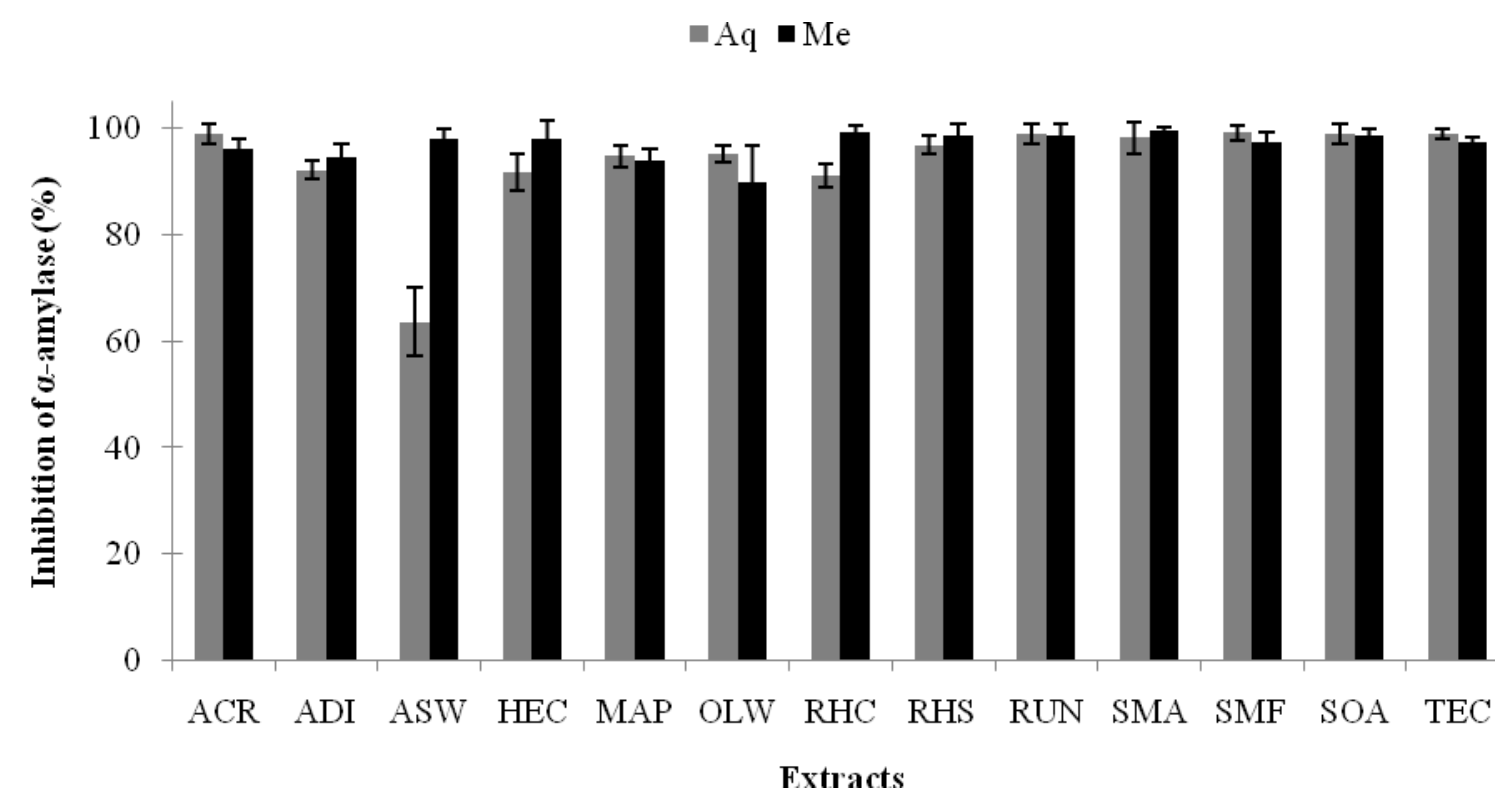

Figure 2. Percentage inhibition (mean \pm SD) of a-amylase activity by extracts of selected antidiabetic plants and acarbose (10 $\mu \mathrm{g}$ each). Note: Aq- aqueous, Me-Methanolic; ACR- Acarbose, ADI- Adiantum incisum, ASW- Asterella wallichiana, HEC- Hedychium coronarium, MAP- Marchantia polymorpha, OLW- Oleandra wallichii, RHC- Rhus chinensis, RHS- Rhus succedanea, RUN- Rubus niveus, SMA- Smilax aspera, SMF- Smilax ferox, SOA- Sonchus arvensis, TEC-Tectaria coadunata 


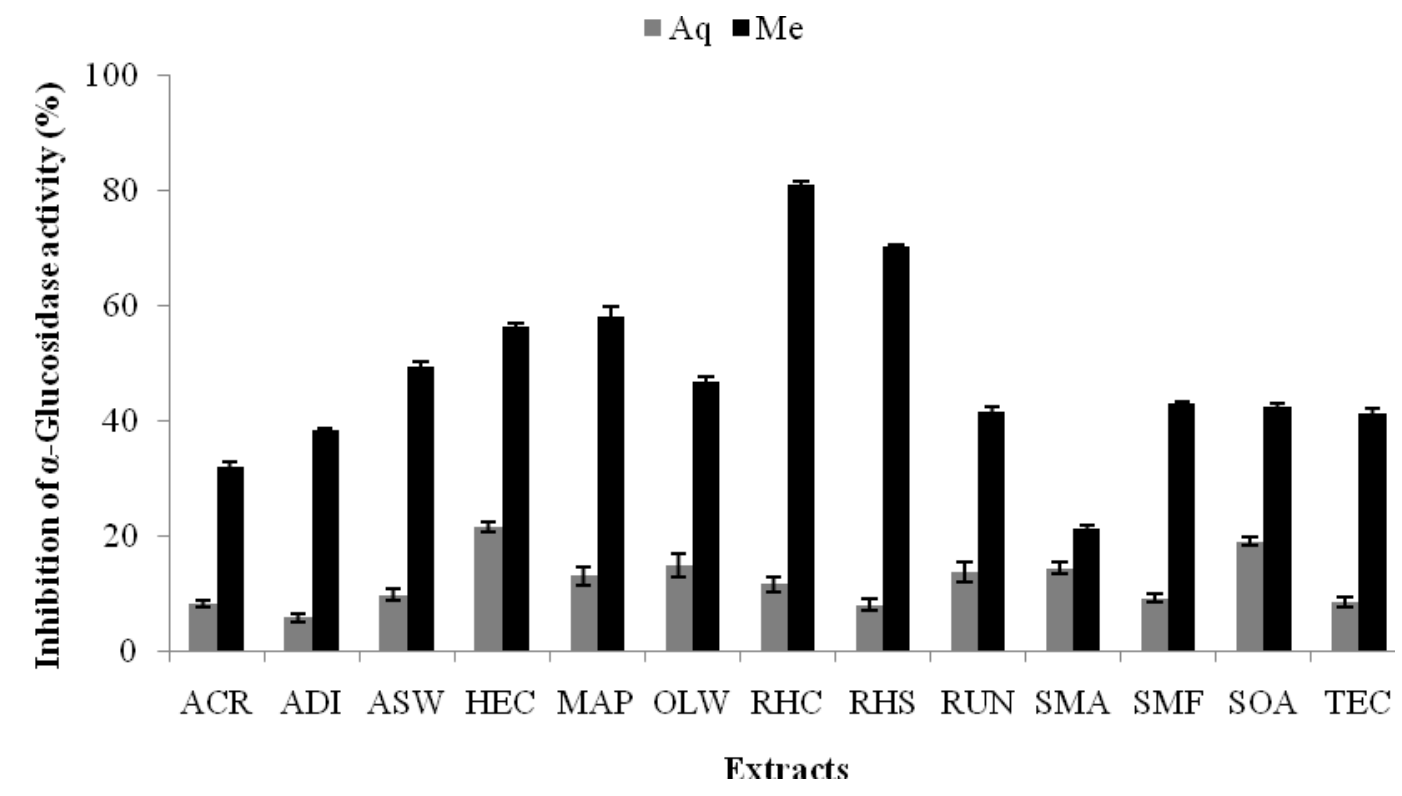

Figure 3. Inhibition of a-glucosidase activity by extracts $(10 \mu \mathrm{g})$ of selected Nepalese antidiabetic plants compared to that of Acarbose $(50 \mu \mathrm{g})$. Note: Aq- aqueous, Me-Methanolic; ACR- Acarbose, ADI- Adiantum incisum, ASW- Asterella wallichiana, HEC- Hedychium coronarium, MAP- Marchantia polymorpha, OLW- Oleandra wallichii, RHC- Rhus chinensis, RHS- Rhus succedanea, RUN- Rubus niveus, SMA- Smilax aspera, SMF- Smilax ferox, SOA- Sonchus arvensis, TEC- Tectaria coadunata

\section{Discussion}

$\alpha$-Amylases are the enzymes of carbohydrate metabolism that convert complex carbohydrates like starch into simple oligosaccharides like maltose. Inhibition of $\alpha$ amylases slows down the downstream processes that lead to the production and absorption of glucose in the intestine. Therefore, these are used as prime targets for lowering post-prandial glucose levels in diabetic patients. Bhandari et al. (2008) studied the antidiabetic potential of 50\% methanolic extracts of 39 Nepalese medicinal plants in terms of inhibition of sucrase, rat intestinal maltase, and porcine pancreatic amylase. They selected 22 species with high inhibitory ability for these enzymes. They also reported least amylase inhibition activity (3.6\%) in Apium graveolens and highest inhibition $(93.5 \%)$ in Bergenia ciliata. The inhibition of porcine pancreatic amylase by extracts of species selected in present investigation is higher than that reported by Bhandari et al. (2008).

The high inhibition of porcine pancreatic amylase by the plant extracts of species in present investigation gives an indication that the antidiabetic/antihyperglycemic activities reported for extracts of species of genera like Adiantum (Saha et al. 2016; Paul et al. 2012), Hedychium (Kaur and Richa 2017; Pranitha et al. 2014), Rubus (Jouad et al. 2002; Alonso et al. 1980), Smilax (Rajesh and Perumal 2013), Sonchus (Sah et al. 2015) and other species used in present investigation is probably achieved through inhibition of $\alpha$-amylase.

$\alpha$-Glucosidase, being one of the key enzymes responsible for glucose production in the digestive system, is considered one of the potential targets in controlling post-prandial glucose levels in type 2 diabetic patients.
Therefore, glucosidase inhibitors are considered as a new hope in the struggle against diabetes. Well over 400 different compounds (61 terpenes, 37 alkaloids, 49 quinines, 103 flavonoids, 37 phenols, 73 phenylpropanoids, 8 sterides, and 43 different other compounds) with glucosidase inhibitory activity have been isolated from different groups of plants (Yin et al. 2014).

Plant extracts along with their active phytoconstituents from different species have been studied for their ability to inhibit $\alpha$-glucosidase in vitro. Abd El-Wahab et al. (2013) reported Berberis vulgaris as one of the most promising plants with high inhibitory activities against $\alpha$-glucosidase. Shim et al. (2003) also reported inhibition of $\alpha$-glucosidase activity in aqueous extracts of Rhus chinensis. The inhibition of $\alpha$-glucosidase activity in present study is comparable to that of Abd El-Wahab et al. (2013) only in the case of methanolic extracts of Rhus chinensis and $R$. succedanea. Since methanolic extract from bark of Rhus javanica (syn. $R$. chinensis) was reported to contain $\alpha$ glucosidase inhibitors like Scopoletin and Phlorizin (Cho et al. 2013), high inhibition of $\alpha$-glucosidase activity by methanolic extracts even in $R$. succedanea may possibly due to the presence of similar compounds. Moderate $\alpha$ glucosidase inhibition activity by plant extracts of selected antidiabetic/antihyperglycemic plants used in present study indicates that the antidiabetic activities in these plants may involve other mechanisms in addition to $\alpha$-glucosidase inhibition as their possible mode of action. Similarly, high degree of $\alpha$-amylase inhibition in extracts of all the tested species suggests that the same mechanism possibly brings about the antidiabetic activities of these plants. Higher inhibition of the activities of enzymes of carbohydrate 
metabolism, especially $\alpha$-glucosidase by methanolic extracts may possibly be due to higher solubility of bioactive compounds in methanol.

Among the extracts of antidiabetic plants tested for their role in inhibiting $\alpha$-amylase activity, all the extracts except the aqueous extract of Asterella wallichiana showed high inhibition of $\alpha$-amylase comparable to that of standard acarbose irrespective of extraction medium (water or methanol). In the case of $\alpha$-glucosidase, however, inhibition was very little in aqueous extracts and moderately high in methanolic extracts. All the species tested showed antidiabetic activity in vitro. These plants should be studied further for their role as antidiabetic/ antihyperglycemic substances in vivo and for search of novel inhibitors of $\alpha$-amylase and $\alpha$-glucosidase.

\section{ACKNOWLEDGEMENTS}

The authors are grateful to the Ministry of Education, Science, and Technology, Government of Nepal for financial support to carry out this research work. The authors would also like to thank Department of Plant Resources, Thapathali, Kathmandu for granting permission to collect plant samples from wild. The support provided by the Central Department of Botany and Central Department of Biotechnology, Tribhuvan University during this research is highly acknowledged.

\section{REFERENCES}

Abd El-Wahab AE, Ghareeb DA, Sharshan EE, Abu-Serie MM, ElDemellawy MA. 2013. In vitro biological assessment of Berberis vulgaris and its active constituent, berberine: antioxidants, antiacetylcholinesterase, anti-diabetic and anticancer effects. BMC Compl Altern Med 13 (1): 218. DOI: 10.1186/1472-6882-13-218.

Ahmed F, Chandra JNNS, Timmaiah NV. 2009. An in vitro study on inhibitory activities of Eugenia jambolana seeds against carbohydrate hydrolyzing enzymes. J Young Pharm 1 (4): 317-321. DOI: 10.4103/0975-1483.59320

Alonso R, Cadavid I, Calleja JM. 1980. A preliminary study of hypoglycemic activity of Rubus fruticosus. Planta Med 40 (1) 102-106. DOI: 10.1055/s-2008-1075012.

Baynes JW, Thorpe SR. 1996. The role of oxidative stress in diabetic complications. Curr Opin Endocrinol 3 (4): 277-284.

Bhandari MR, Jong-Anurakkun N, Kawabata J. 2008. Antidiabetic potential of Nepalese medicinal plants. In: Martirosyan DM (ed) Functional Foods for Chronic Diseases. D \& A Inc., Texas, USA.

Bosenberg LH, van Zyl DG. 2008. The mechanism of action of oral antidiabetic drugs: A review of recent literature. J Endocrinol Metab Diabetes S Afr 13: 80-88. DOI: 10.1080/22201009.2008.10872177.

CDC. 2007. National Diabetes Factsheet. Centre for disease control and prevention, US department of health and human services. stacks.cdc.gov/view/cdc/5613/cdc_5613_DS1.pdf

Cho JY, Lee KD, Park SY, Jeong WC, Moon JH, Hang KS. 2013. Isolation and identification of $\alpha$-glucosidase inhibitors from the stem bark of nutgall tree (Rhus javanica Linne). J Korean Soc Appl Biol Chem 56 (5): 547-552. DOI: 10.1007/s13765-013-3140-7.

Dahal A. 2016. Ethnobotanical study of medicinal plants used by traditional healers in the management of diabetes mellitus in Sankhuwasabha, Nepal. Intl J Ayurveda Pharm Res 4: 65-70.
Farzaei F, Morovati MR, Farjadmand F, Farzaei MH. 2017. A mechanistic review on medicinal plants used for diabetes mellitus in traditional Persian medicine. J Evid Based Compl Altern Med 22 (4): 944-955. DOI: $10.1177 / 2156587216686461$.

Ibraheim ZZ, Ahmed AS, Gouda YG. 2011. Phytochemical and biological studies of Adiantum capillus-veneris L. Saudi Pharm J 19 (2): 65-74. DOI: 10.1016/j.jsps.2011.01.007.

Joshi K. 2011. Ethnobotanical study of plants used for the treatment of diabetes mellitus in the mountainous regions of Nepal. J Non-timber For Prod 18 (1): 19-26.

Jouad H, Maghrani M, Eddouks M. 2002. Hypoglycaemic effect of Rubus fructicosis L. and Globularia alypum L. in normal and Streptozotocin-induced diabetic rats. J Ethnopharmacol 81 (3): 351356. DOI: 10.1016/s0378-8741(02)00118-6.

Kaur H, Richa R. 2017. Antidiabetic activity of essential oil of Hedychium spicatum. Intl J Pharmacogn Phytochem Res 9: 853-857. DOI: 10.25258/phyto.v9i6.8190.

Lipinski B. 2001. Pathophysiology of oxidative stress in diabetes mellitus. J Diabet Complic 15: 203-210. DOI: 10.1016/S1056-8727(01)00143$\mathrm{X}$.

Manandhar N, Rokeya B, Ali L, Amatya S. 2011. Antidiabetic effects of Neopicrorrhiza schrophulariiflora on type 2 diabetic model rats. J Inst Med Nepal 33: 53-57.

Marles RJ, Farnsworth NR. 1995. Antidiabetic plants and their active constituents. Phytomedicine 2: 137-189. DOI: 10.1016/S09447113(11)80059-0.

Mukhia S, Mandal P, Singh DK, Singh D. 2017.Study of bioactive phytoconstituents and in vitro pharmacological properties of thallose liverworts of Darjeeling Himalaya. J Pharma Res 11: 490-501.

Patil R, Patil R, Ahirwar B, Ahirwar D. 2011. Current status of Indian medicinal plants with antidiabetic potential: a review. Asian Pac J Trop Biomed 1: S291-S298. DOI: 10.1016/S2221-1691(11)60175-5.

Paul T, Das B, Apte KG, Banerjee S, Saxena RC. 2012. Evaluation of antihyperglycemic activity of Adiantum philippense Linn., a pteridophyte on alloxan-induced diabetic rats. J Diabetes Metab 3 (9): 226. DOI: $10.4172 / 2155-6156.1000226$.

Pietropaolo M, Roith DL 2001. Pathogenesis of diabetes: Our current understanding. Clin Cornerstone 4: 1-16. DOI: 10.1016/S10983597(01)90025-0

Pranitha K, Salini K, Pratibha M, Suneha S. 2014. Hypoglycemic action of ethanolic extract of Hedychium coronarium Linn Rhizome in alloxan-induced diabetes in rat model. Intl $\mathrm{J}$ Res Pharmacol Pharmacotherapeut 3: 211-221.

Rajesh V, Perumal P. 2014. In vivo assessment of antidiabetic and antioxidant activities of methanol extract of Smilax zeylanica leaves in Wistar rats. Orient Pharm Exp Med 14 (2): 127-144. DOI: 10.1007/s13596-013-0137-z.

Sah JP, Poudel BP, Subedi SR, Amatya S, Shrestha TM, Amatya MP. 2015. Hypoglycemic and analgesic effects of methanolic extract of Sonchus arvensis from Nepal. Intl J Pharmacogn Phytochem Res 97: 613-615.

Saha D, Ghosh SK, Das T, Mishra SB. 2016. Hypoglycemic and antihyperlipidimic effects of Adiantum caudatum in alloxan-induced diabetic rats. Asian J Pharm Clin Res 9: 339-341.

Shim YJ, Doo HK, Ahn SY, Kim YS, Seong JK, Park IS, Min BH. 2003. Inhibitory effect of aqueous extract from the gall of Rhus chinensis on alpha-glucosidase activity and postprandial blood glucose. J Ethnopharmacol $85 \quad(2-3)$ : 283-287. DOI: $10.1016 / \mathrm{S} 0378-$ 8741(02)00370-7.

Si MM, Lou JS, Zhou CX, Shen JN, Wu HH, Yang B, He QJ, Wu HS. 2010. Insulin releasing and alpha-glucosidase inhibitory activity of ethyl acetate fraction of Acorus calamus in vitro and in vivo. $\mathbf{J}$ Ethnopharmacol 128 (1): 154-159. DOI: 10.1016/j.jep.2009.12.044.

Singh AG, Kumar A. 2017. Ethnomedicinal aspects of climbing plants of Palpa district, Nepal. Trop Plant Res 4: 307-313. DOI: 10.22271/tpr.2017.v4.i2.040.

WHO. 2016. Global Report on Diabetes. World Health Organization, Geneva.

Yin Z, Zhang W, Feng F, Zhang Y, Kang W. 2014. $\alpha$-Glucosidase inhibitors isolated from medicinal plants. Food Sci Hum Well 3 (3-4): 136-174. DOI: 10.1016/j.fshw.2014.11.003. 